\title{
Integration of Critical Thinking Skills in Science Learning Using Blended Learning System
}

\section{Ferrinda Prafitasari*, Sukarno ${ }^{2}$, Muzzazinah3}

1,2,3 Master of Primary School Teacher Education Study Program, Sebelas Maret University, Indonesia

\section{ART ICLE INFO}

Article history:

Received June 15, 2021

Revised June 20, 2021

Accepted July 25, 2021

Available online August 25, 2021

Kata Kunci:

Berpikir Kritis, Blended Learning, IPA

Keywords:

Critical Thinking Skills, Mixed

Learning, Science

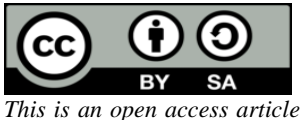

This is an open access article under the CC BY-SA license.

Copyright (C) 2021 by Author. Published by Universitas Pendidikan Ganesha.

\begin{abstract}
A B S T RA K
Pandemi covid-19 menyebabkan semua bidang menghadapi situasi yang menantang. critical thinking skill tetap harus diintegrasikan dalam pembelajaran IPA dengan situasinya karena merupakan salah satu aspek pembelajaran abad 21. Alternatif untuk mengurangi kegiatan tatap muka maka sekolah melaksanakan pembelajaran dengan sistem campuran. Tujuan penelitian ini untuk mengevaluasi integrasi critical thinking skill pada pembelajaran IPA menggunakan blended learning system di sekolah dasar mengingat adanya batasan-batasan dalam pembelajaran pada pandemi covid-19. Penelitian merupakan penelitian kualitatif kasus dengan proporsi deskriptif dengan sampel sebanyak 19 siswa kelas $V$ sekolah dasar. Teknik pengumpulan data yang digunakan adalah observasi, dokumentasi, angket, dan wawancara. Triangulasi sumber dan teknik yang digunakan untuk memvalidasi data. Hasil penelitian menunjukkan bahwa critical thinking skill pada pembelajaran IPA sekolah dasar menggunakan blended learning system masih tergolong rendah dengan data $(M o<M d<M e)$, mean=14,10 dan distribusi frekuensi terbesar persentase 47,37\%. Persentase kuisioner mayoritas menjawab tidak pernah dengan rincian aspek merumuskan masalah 52,63\%, menganalisis argumen dan memecahkan masalah 48,42\%, mengevaluasi 57,89\%. Kesimpulannya pengintegrasian critical thinking skill dengan blended learning system di sekolah dasar pada pembelajaran IPA masih perlu dipertimbangkan karena masih ada kendala dalam pelaksanaannya. Hasil penelitian ini berimplikasi pada pencarian solusi untuk meningkatkan critical thinking skill pada pembelajaran IPA dengan pembelajaran blended learning system agar lebih efektif. Rekomendasi dalam penelitian ini guru lebih kreatif dalam menerapkan strategi pembelajaran blended learning system agar keberhasilan critical thinking skill pada pembelajaran IPA peserta didik dapat tercapai dengan baik.
\end{abstract}

\section{A B S T R A C T}

The COVID-19 pandemic has caused all fields to face a situation that challenging. critical thinking skills must still be integrated into science learning with the situation because it is one aspect of 21st-century learning. An alternative to reducing face-to-face activities is that schools carry out mixed-system learning. The purpose of this study was to evaluate the integration of critical thinking skills in science learning using a blended learning system in elementary schools given the limitations in learning during the covid-19 pandemic. This research is a case qualitative research with descriptive proportion with a sample of 19 elementary school fifth-grade students. Data collection techniques used are observation, documentation, questionnaires, and interviews. Triangulation of sources and techniques used to validate data. The results showed that critical thinking skills in elementary school science learning using a blended learning system are still relatively low with data $(\mathrm{Mo}<\mathrm{Md}<\mathrm{Me})$, mean $=14.10$, and the largest percentage distribution of $47.37 \%$. The percentage of the majority of the questionnaires answered never with details on the aspects of formulating the problem $52.63 \%$, analyze arguments and solve problems $48.42 \%$, evaluate $57.89 \%$. In conclusion, the integration of critical thinking skills with blended learning systems in elementary schools in science learning still needs to be considered because there are still obstacles in its implementation. The results of this study have implications for finding solutions to improve critical thinking skills in science learning with blended learning system learning to be more effective. The recommendation in this study is that teachers are more creative in implementing blended learning system learning strategies for success critical thinking skills in learning science students can be achieved well.

\section{INTRODUCTION}

Education around the world experienced disruptions in face-to-face teaching during the 20192021 academic year due to the COVID-19 pandemic, so the government issued a distance learning policy. The government issued a policy for all students to study at home, to reduce social activities outside the home. During the extended school closures, many working parents struggle to educate and care for their children(Fitriyani et al., 2020; Harris \& Larsen, 2018). Thing This is a unique challenge in the world of 
education as this pandemic has had a wider impact on society accompanied by a massive economic downturn, job losses, widespread protests over financial injustice, and the real health threat of COVID-19 (Herliandry et al., 2020; Kuhfeld et al., 2020). The public health concerns posed by the COVID-19 outbreak have driven online learning at the same time. Teachers and educators must undergo the ongoing massive migration from conventional face-to-face education to distance education as a basic element of teaching, even though educators and learners are in several locations (Dewi, 2017; Irawan et al., 2015; Susanti, 2019).

The hope is that during the COVID-19 pandemic, critical thinking skills must still be integrated into learning. Critical thinking skill is one of the 21st-century competencies that must be included in learning in abstract science material that cannot be observed directly as one of the 21 st-century skills. To obtain optimal abilities, it is important to cultivate the habit of building knowledge to find solutions to problems. problem. Thoughts and breakthroughs are required for the 21st century's ability to produce competitively high-quality goods. Critical thinking skills are used to counteract and filter extremism that is considered irrational through reasoning, analysis, and problem-solving. The demands of digital knowledge require critical thinking skills. Students should be able to understand the 4C capabilities in the 21st century. Critical thinking skills encourage the assessment and application of knowledge. The purpose of integration is to improve skills so that all student competencies can increase understanding and activity (Yu \& Wan Mohammad, 2019). National Education System Law No. 20 of 2003 states that education is a systematic effort to create a learning process for students to actively develop themselves in religious spiritual strength, personality, self-control, and intelligence needed by themselves, society, and the state. Problems in education include learning focused on the theory which results in less development of thinking, learning that is less relevant to the environment, supervision, teaching professionalism (Sutisna et al., 2020; Indraswati et al., 2020).

The results of preliminary observations that occurred at SDIT Mutiara Boyolali in the implementation of critical thinking skills integration, $75 \%$ of students stated that the integration of critical thinking skills in learning was not fully integrated during the covid-19 pandemic. This is because in its implementation there are still many obstacles that are still experienced by teachers and students. After all, the system is being implemented for the first time in an emergency of the covid 19 pandemics. The general obstacle during face-to-face learning is time constraints, while online learning constraints are the limitations of the teacher's technological ability and student parents. There are many learning platforms available, but the teacher only informs the material through the WhatsApp platform and the teacher sends more assignments than the material. Students improve critical thinking skills to be more effective by working together or using concept mapping than by working individually using traditional training methods (Huang et al., 2017). Whereas in science learning these things must be mastered by students so that learning runs as it should. Teachers and students have technological limitations in the distance learning process (Reflianto \& Syamsuar, 2018).

Solutions in the new normal era in the world of education that has had an impact so far can begin to run gradually. The new normal era of reform in the field of education has begun to be implemented from online learning to mixed learning. Learning that combines face-to-face and online is called a blended learning system which is proven to be a superior method combining various learning methods, pedagogical approaches, and internet technology (Seage \& Türegün, 2020; Widiara, 2018). References for learning innovations and methods to improve the learning process with blended learning systems (Bi \& Shi, 2019). The application of the blended learning system has a positive impact on students' metacognition, mixed learning enhances the experience through various online sources, and project assignments that can be shared (Indriyanti \& Yamtinah, 2020). Support from principals, teachers to develop the relevance of varied learning on the blended learning system in schools (Tayag, 2020). Learning with a blended learning system can increase the involvement of students to take part in learning (He \& Zhao, 2020) (He \& Zhao, 2020).

The novelty of this research based on previous research is to specifically evaluate each aspect of critical thinking skills in science learning in elementary schools during the covid-19 pandemic which limits all activities, where blended learning systems are generally implemented in high schools and universities due to the use of technology in the blended learning system which is certainly different from the implementation in elementary schools. Previous research to strengthen the novelty of this research, among others, states that: blended learning system can change the roles of teachers and students, elearning is interesting because it increases the clarity of learning to individuals, the learning process, and feedback. Both teachers and students feel a lack of basic human contact and communication (Kacetl \& Semradova, 2020). This research focuses on a blended learning system without specificity to critical thinking skills as 21st-century skills. Mixed learning involving web-based instruction and face-to-face instruction can provide strong support for developing competencies and student critical thinking skills 
(Wannapiroon, 2014). But previous research was not carried out during a pandemic emergency so the results would be different from emergency conditions. Model development blended learning system Upgrade critical thinking skills college student (Boa et al., 2018). The difference of this study from previous research is the subject and focus of the material. The subjects in the previous study were students and were not focused on learning science, while this study focused on the scope of elementary schools and learning science.

The urgency of this research is to evaluate the implementation of the blended learning system in science learning in elementary schools to find advantages and constraints in its implementation, if there are advantages it can be used as a reference, while if there are obstacles, solutions can be found to overcome obstacles because the blended learning system is one alternative that can be applied during a pandemic that requires restrictions on social activities. Schools can also use blended learning systems to comply with government regulations while still implementing the learning system. This research was carried out because it can be used as a consideration for alternative learning systems during the COVID-19 emergency. Given the importance of material and critical thinking skills in science learning, it is necessary to research to evaluate how to integrate critical thinking skills in science learning using a blended learning system so because a blended learning system is a new alternative in the current state of the Covid-19 pandemic emergency. The results of this study have implications for the evaluation of looking for strengths and obstacles to find solutions to improve critical thinking skills in science learning with blended learning system learning so that its implementation is more effective. The recommendation in this study is that teachers are more creative in implementing blended learning system learning strategies so that the success of critical thinking skills in students' science learning can be achieved properly.

\section{METHOD}

This research was conducted using qualitative research and descriptive research design of heat material learning in the Natural Sciences (IPA) sub-discussion to evaluate the integration of students' critical thinking skills in science learning using a blended learning system. The subjects in the study were class V which consisted of 2 teachers and 19 students. Data collection techniques were carried out to collect data. Data collection techniques in this study were interviews and research observations on several things related to data collection on student behavior habits. Questionnaires were given to strengthen the data. Documentation in the form of data on student work and photos. This technique is used by researchers to extract data, information, and information framework from research subjects. The type of interview used is semi-structured. This type of interview falls under the category of in-depth interviews, which in practice are more independent than structured interviews. The purpose of semi-structured interviews is to find problems more openly, where informants are asked for their opinions and ideas. The subjects interviewed in this study were students, teachers, and principals at SDIT Mutiara Boyolali, Central Java. The purpose of this interview is to collect data about the integration of students' critical thinking skills in science learning using a blended learning system during a pandemic COVID-19. The observation process is carried out so that the data obtained can be accounted for. The next data collection is a questionnaire. This technique is used to obtain information from respondents about their personality, or other things they know. The instruments grid is shown in Table 1.

Table 1. Critical Thinking Skills Integration in Science Learning with Blended Learning System Instruments Grid

\begin{tabular}{lll}
\hline No & \multicolumn{1}{c}{ Aspect } & \multicolumn{1}{c}{ Description } \\
\hline 1 & $\begin{array}{l}\text { Formulate } \\
\text { problem }\end{array}$ & $\begin{array}{l}\text { 1. Determine what is known and asked about the problem } \\
\text { 2. Explain the result of the problem }\end{array}$ \\
2 & $\begin{array}{l}\text { Analyze and } \\
\text { solve problems }\end{array}$ & $\begin{array}{l}\text { 1. Identify the elements of the problem } \\
\text { 2. Formulate the alleged solution of the problem } \\
\text { 3. Distinguishing right and wrong } \\
\text { 4. Develop a settlement plan } \\
\text { 5. Solve questions until you get the correct answer }\end{array}$ \\
& & $\begin{array}{l}\text { 1. Make a conclusion } \\
\text { 2. Checking the results again }\end{array}$ \\
\hline 3 & Evaluate &
\end{tabular}

Descriptive calculations of percentages are then interpreted into sentences. Critical thinking skill score data is the total score of all critical thinking skill indicators in science learning using a blended 
learning system. PAP (Based Reference Assessment) will be used to change the average score. The validity of the data using triangulation techniques and sources. Triangulation aims to collect data as well as test the credibility of the data, namely checking the credibility of the data using various techniques, namely observation, documentation, interviews, and questionnaires, and data sources from various sources. Data analysis techniques by way of data are arranged, sorted, grouped, then categorized according to the Miles \& Huberman model including data collection, data reduction, data presentation, and concluding. Data in the form of test scores were analyzed according to the rubric provided, then the data was described and then analyzed by determining the type of descriptive percentage obtained by each indicator.

\section{RESULT AND DISCUSSION}

\section{Result}

The results of the study contain an overview of critical thinking skills data, efforts, and obstacles in developing critical thinking skills in science learning with a blended learning system. The integration of critical thinking skills in learning helps students build knowledge so that they are accustomed to finding solutions to solve problems using combination learning or blended learning systems. During the COVID19 pandemic, learning is carried out both face-to-face and online using a blended learning approach. Each of these three days of online and offline learning alternates. In one day, face-to-face learning can be completed in three hours. Learn online with WhatsApp, take advantage of all available features such as voice notes, video calls, and time flexibility. Teachers make various learning media, such as educational videos, photos, sounds, and pictures. Aspects of critical thinking skills consist of formulating problems, analyzing and solving problems, and evaluated as follows.

\section{Formulate the problem}

Formulating problems is an aspect of critical thinking skills, in this aspect the aspect of formulating problems in learning has been applied in learning. Obstacles during learning are when determining what is known and asked in questions, students do not write down problems and are asked questions so that they cannot explain the results of problem analysis. This is because when learning takes place some students have a sense of confidence and fear of being laughed at by other students when asking for material that is not understood so that when given questions students are not accustomed to writing down problems and explaining problems. The following are the results of the student's answers to the questionnaire about critical thinking skills in the aspect of formulating problems presented in Figure 1. The percentage of all aspects of formulating the problem in the chart above is the highest indicator of choice, never with a percentage of $52.63 \%$, so that when learning science with the blended learning system was not well integrated.

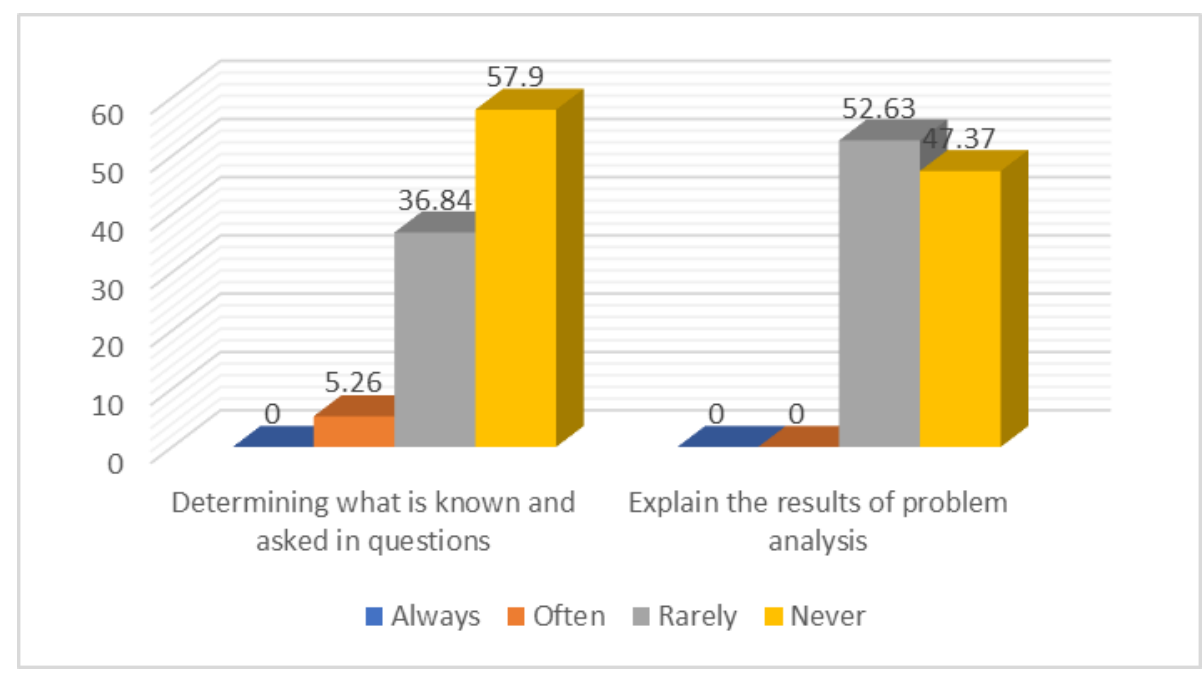

Figure 1. Results of Students' Questionnaire Answers on Aspects of Formulating Problems

\section{Analyze and solve problems}

Analyze and solve problems Identifying the elements of the problem, students write down the details of the problems that have been found, the majority of students only write down the problem without analyzing what elements are in the problem. Compile the alleged problem solving, at this stage not all students write down the alleged solution to the problems found, but only a small number of 
students' write. Distinguishing right and wrong, not all students distinguish true and false statements on questions, some students feel confused. Compile a settlement plan, not all students have written a problem-solving plan from the identification of science problems during learning, but all students are trying to solve the problem until they get the right answer. When learning has several obstacles, namely the limited time for face-to-face discussions considering the time that was applied during the covid-19 pandemic was only 3 hours per day and was still divided into several different subjects, so that when learning thematic material, especially heat material in science, was still limited. The teacher has not familiarized students with differentiating right and wrong opinions by provoking students with High Order Thinking Skill (HOTS) questions. Students focus on working on the questions given to get the right answers and try to write down the answers when asked questions orally or in writing, but when working on written questions when online learning cannot be monitored by the teacher directly. The percentage of students' ability to analyze and solve problems analyzing and solving problems has never been with a percentage of $48.42 \%$ so that when learning science with the blended learning system has not been well integrated.

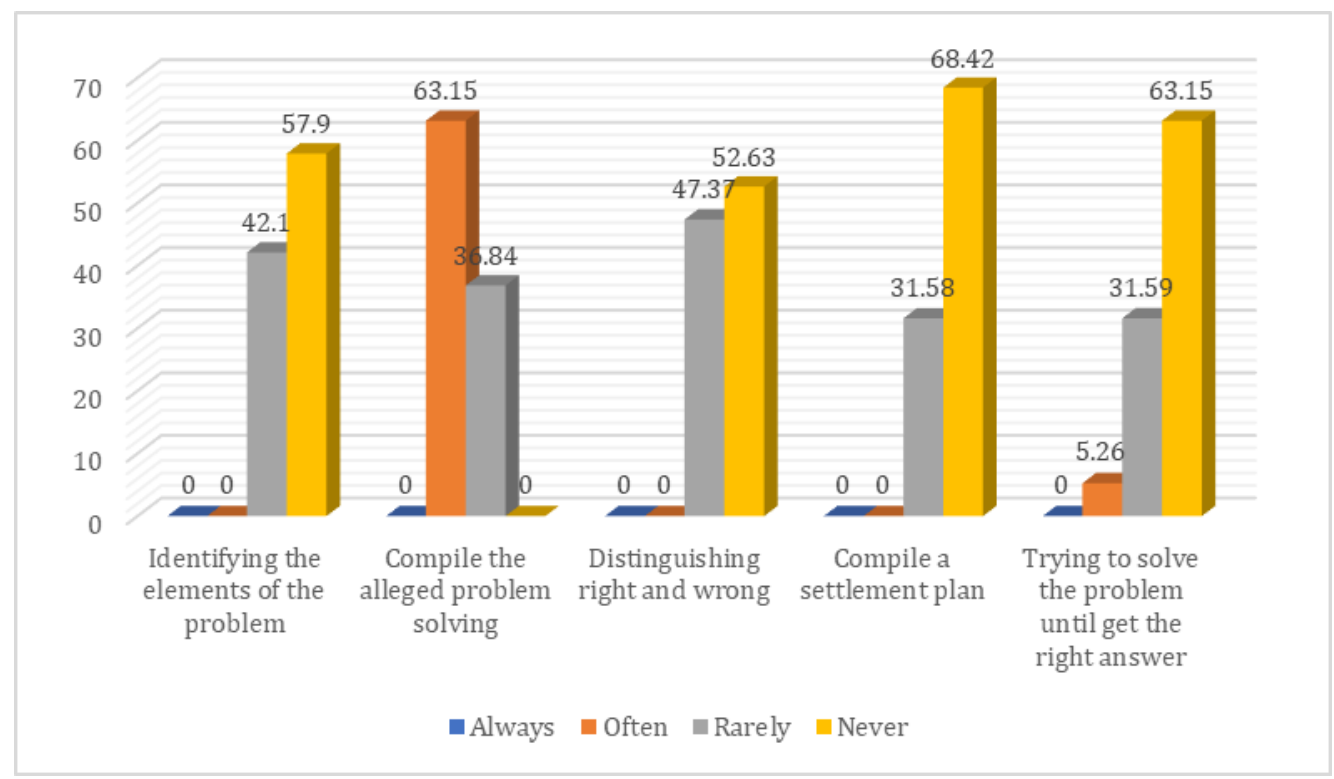

Figure 2. The Results of Students' Questionnaire Answers on Aspects of Analyzing and Solving Problems

\section{Evaluate}

Evaluation skills that students have when giving conclusions based on observations and experiences that have been found in everyday life but without revealing the concept. When collecting assignments or questions to the teacher, students re-examine the results of the work so that no work is missed or lacking. The percentage of ability to evaluate the majority never with a percentage of $57.89 \%$ so that when learning science with the blended learning system has not been well integrated.

\section{Discussion}

The integration of critical thinking skills in learning helps students build knowledge so that they are accustomed to finding solutions to solve problems using combination learning or blended learning systems. During the COVID-19 pandemic, learning is carried out both face-to-face and online using a blended learning approach. The COVID-19 pandemic has changed the order in education. Even during the COVID-19 pandemic, development efforts critical thinking skills students have to keep trying. Despite changes in learning due to COVID-19, the application of innovative methodologies must be able to align competencies and skills while responding to student needs quickly, maintaining class dynamics, and motivating learning so that learning can still achieve its goals (Ripoll et al., 2021). Development efforts critical thinking skills during the pandemic in various ways, one of which is using a blended learning system. The Blended Learning system is alternative learning that can be applied during a pandemic because it combines face-to-face learning and online learning, even though during a pandemic it still has various limitations. Classblended learning systems have better learning efficiency, the approval rate is significantly higher for students from schools that do not stop face-to-face educational activities than students from schools that are closed, but also have various obstacles in the covid-19 situation. The COVID-19 widespread has opened up space for online teaching instructing with a whole new perspective 
for teacher and students. New teaching methods online education requires teachers to change the old teaching paradigm to that are also in line with technology. Direct consultation with students on teaching styles is important to check whether students are following the lesson and help identify various aspects of learning that need to be adapted. (Lapitan et al., 2021).

Students' critical thinking skills in science learning with blended learning system in the low category because they still have problems in learning. The solution to overcome this is for critical thinking skills can be implemented with activities related to discussions with an explicit approach to developing critical thinking because the use of an implicit approach is less effective in learning (Bellaera et al., 2021). Critical thinking skills must be integrated into learning to develop knowledge and be accustomed to solving difficulties. Importance critical thinking skills must be based on the quality of reasoning rather than just the ability to choose the right answer (Hart et al., 2021). Until critical thinking skills, It is very important to be integrated into learning because it is related to reasoning abilities. Use a blended learning system improves the accessibility of learning anywhere by utilizing relevant technology and following established guidelines to help students. Teachers encourage online learning activities by allowing students to use WhatsApp's video call and voice note features to ask questions.

Students' academic abilities are enhanced by case-centered integrated learning, with a blended learning system in online and offline learning so that a suitable educational approach to improving critical thinking skills (Z. Yu et al., 2021). Online project-based learning encourages the development of critical thinking, while socially relevant regulations also have a significant impact due to the COVID-19 pandemic (Cortázar et al., 2021). Distance learning that combines webinars and virtual simulations can meet the requirements of learning in a safe environment flexibly and can gain theoretical knowledge and develop critical thinking skills during the COVID-19 pandemic (Luo et al., 2021). Critical thinking skills must understand the importance of media and information literacy in enabling skills to interact with social media (Zou'bi, 2021). Critical thinking skills show students' curiosity and concern for the information obtained in the learning class. Mixed learning systems support increasing their capacity to understand data and draw conclusions based on analysis. Free time is used by teachers and students to communicate intensively (Hikmah, and Chudzaifah 2020; Hasanah et al. 2020). Educators can use a blended learning system to optimize the learning process to get the best results by adapting to needs, increasing attractiveness, and prevent the spread of COVID-19. Critical thinking skills need to be improved again to be more optimal (Lazem, 2019; Lim et al., 2020; McKenzie et al., 2020; Wahyuni et al., 2019).

Formulating problems is an aspect of critical thinking skills, in this aspect the aspect of formulating problems in learning has been applied in learning, but due to the COVID-19 pandemic, it has not been implemented optimally. The percentage of all aspects of formulating a problem on the highest chart is an indicator of choice, never with a percentage of $52.63 \%$, so that when learning science with the blended learning system was not well integrated. It is that the COVID-19 pandemic forced all learning processes to be carried out online as a solution to continue the education process in difficult times like these. The COVID-19 pandemic can disrupt student anxiety (Ćosić K et al., 2020; Kar et al., 2020; Lee, 2020; Polizzi et al., 2020). Difficulties in online learning are not only experienced by students in elementary schools, but students also experience almost the same difficulties. Online learning can have both positive and negative impacts on students (Sukardi \& Rozi, 2019).

The problem during learning is when determining what is known and asked in the question, students do not write down the problem and are asked the question so that students cannot explain the results of the problem analysis. This is because when learning takes place some students have a sense of self-confidence and fear of being laughed at by other students when asking questions that are not understood so that when given questions students are not accustomed to writing down problems and explaining problems. The process so that individuals who think critically have the ability to ask questions correctly, reduce relevant information so that they can formulate problems (Pursitasari et al., 2020). Exercises to formulate a problem can practice making arguments to make students more detailed when examining a problem, and this includes examining beliefs in self and beliefs of others. Doing so allows them to better understand other people's thoughts during discussions, thereby increasing understanding and argument construction (Kaeppel, 2021). Overcoming students' anxiety and possible boredom in learning by shifting learning from a teacher-centered learning system to a student centre and providing motivation. How to overcome the anxiety and possible boredom of students' learning by shifting learning from a teacher-centered learning system to a student centre whose pattern is adjusted to the conditions during science learning (Çetin, 2016; Turgut et al., 2016).

Teachers can provoke students with problem-based questions when learning using a blended learning system because it increases critical thinking skills and understanding in formulating and explaining a problem. Teachers can provoke students with problem-based questions when learning using a blended learning system because it increases critical thinking skills and understanding in formulating 
and explaining a problem (Marnita et al., 2020). Teachers can design patterns of interaction and communication by using methods that emphasize more on effective information seeking. Teachers can design patterns of interaction and communication by using methods that emphasize more on effective information seeking by students so that critical thinking skills will appear in students during the learning process in class (Rahmat et al., 2020). The use of e-modules can improve critical thinking. Learning by formulating problems through a virtual learning environment. The use of e-modules can improve students' critical thinking to be able to formulate a problem (Budiarti et al., 2016). Learning by formulating problems through a virtual learning environment improves learning abilities and problemsolving skills among students (Phungsuk et al., 2017).

Analyze and solve problems the percentage of the majority answered never as big as $48.42 \%$ so that when learning science with the blended learning system has not been well-integrated students write down the details of the problems that have been found, the majority of students only write down the problems without analyzing what elements are there. even though analyzing and solving problems can enhance critical thinking to analyze and solve which prepares them for their future careers real problems. This remarkable development in teaching approaches has increased teaching effectiveness (Alrahlah, 2016). The activity of analyzing the problem aims to guide students to think more broadly, provide a challenge, test mathematical rather than procedural abilities, and enrich learning resources (Shivam \& Singh, 2015). The solution is that teachers teach based on problems in everyday situations to lead students to have a sense of obligation to solve them, therefore they are aware of the importance of finding the right concepts and knowledge to solve the problems they face using various sources of information. As a means of logical and critical thinking, the teacher facilitates the problem-solving process through contextual situations (Diputra, 2018; Gede Astawan et al., 2020; Riastini \& Mustika, 2017).

Compiling the allegation of solving the problem, not all students write down the alleged solution to the problems found, but only a small number of students' write. This is because the teacher has not familiarized students with differentiating right and wrong opinions by provoking students with High Order Thinking Skill (HOTS) questions. The solution is that teachers can get used to giving High Order Thinking Skills (HOTS) questions during face-to-face and online learning via WhatsApp. This is to get used to evaluating real situations that are relevant to daily activities (Laksana et al., 2019). Critical thinking skills provide a thorough understanding of the problem. Students are actively involved in scientific activities using the scientific method, which allows them to develop critical thinking skills. The teacher must always prepare questions that will come later not answered simply, but through a systematic problem-solving strategy, as a concept of developing the problem of High Order Thinking Skill students' critical thinking skills can be seen from the way students respond to existing mathematical problems (Ariandari, 2015). Giving High Order Thinking Skill (HOTS) questions ranging from simple to sophisticated develops stronger knowledge. The teacher should explain the concepts obtained from internet to expand knowledge expand scientific journals, or the textbooks (Laksana et al., 2019; Saptuti Susiani et al., 2018; Shaheen, 2016).

Distinguishing right and wrong, not all students distinguish true and false statements on questions, some students feel confused. This is due to a lack of reading habits to understand concepts material before class hours and network constraints during online learning hours. So when asked questions tend to be confused. When given a written question, their ability to complete the question until they receive the correct answer can be seen in their answers. Students focus on working on the questions until they get the correct answer but identify the elements of the problem in the problem, students write down the details of the problems that have been found, the majority of students only write down the problem without analyzing what elements are in the problem. The solution combines blended learning system learning with problem-based learning models and the use of learning media. Students can read the material before class hours. This success is strongly supported by learning activities that meet several criteria for active learning, innovation, students' critical thinking, and problem-solving skills collaboration, creativity and innovation, communication information skill media, and technology (Anazifa \& Djukri, 2017; Çetin, 2016). The existence of learning videos, detailed explanations in each sub-material as well as direct discussions and investigations strongly support the emergence of various indicators of critical thinking skills (Marnita et al., 2020).

Compile a settlement plan, not all students have written a problem-solving plan from the identification of science problems during learning, but all students are trying to solve the problem until they get the right answer The solution person parents are required to maintain the rhythm of student learning as appropriate learning at school. There is a schedule and a series of lessons that the teacher continues to monitor through online media, while parents have to make sure everything goes well. Critical students to be more active in solving problems, including active asking questions to obtain clear information, courage to express opinions and ideas they have to criticize solutions that they think are 
rational, seriousness in working on existing problems to obtain logical solutions and able to conclude existing mathematical solutions (Indraningtias \& Wijaya, 2017). Changes in learning methods require all groups to comply with all possible ways so that the learning process can run well, and the choice is to use technology as a means of the online learning process. The use of this technology is not without obstacles, several factors that hinder the effectiveness of online learning, including low mastery of technology, limited facilities and infrastructure, internet networks, and costs (Andiarna \& Kusumawati, 2020; Purmadi \& Hadi, 2018). When asking a question verbally, solve it directly by trying to provide an answer. The solution is that students must be given procedural steps accompanied by pictures or videos to understand the instructions for experimental activities. If they are not accompanied by this, they will not understand the direction of the experimental activities. Students write down various problem-solving procedures. Teachers should be aware that every student has different skills, and if possible, they should pay more attention to lower abilities. Someone with critical thinking skills will be tasked with turning criticism into constructive criticism that will contribute to better problem solving (Essel et al., 2017).

Evaluating is an aspect of critical thinking skills percentage of ability to evaluate the majority never with a percentage of $57.89 \%$ so that when learning science with the blended learning system has not been well integrated. Mixed learning involving web-based instruction and face-to-face instruction can provide strong support for developing competence and critical thinking skills (Wannapiroon: 2014). Students double-check their work when submitting assignments to make sure no work is missed. Students are instructed to explain the reasons for giving answers or conclusions based on the findings of analysis and problem solving to demonstrate their ability to conclude experimental data. Limited to this, students provide conclusions based on observations and experiences that have been found without revealing the concept. The solution is that the teacher as a facilitator helps the group build understanding and connect concepts by providing information, directing exploration, strengthening understanding of difficult concepts, and introducing resources. In addition, the facilitator asks for a reflection on the group process and group results. Facilitators can also be considered as coaches or guides who provide feedback and encouragement (Seibert, 2021). Teachers provide opportunities for students to be able to evaluate their thinking and change students' thinking behavior so that they can apply the knowledge they already have (Alghafri \& Ismail, 2014).

Critical thinking is the process of thinking of an individual to investigate the reasons that exist and analyze the available information to conclude so that the individual can make decisions and make judgments (DeWaelsche, 2015; Pursitasari et al., 2020). So that students should master this as a way to make decisions. Activities in evaluating examine, relate and evaluate all aspects of a situation or problem, including gathering, organizing, remembering, and analyzing information (Ariandari, 2015). The solution is that the teacher can make an effort by asking students to read the book first to help them understand the concept. Troubleshooting is used to improve critical thinking skills to find concepts that have been learned (open-ended) independently. The teacher invites students to read the reading text provided in the book. Students should be able to gain new knowledge on their own from what they read and discuss it in groups. Thus the interaction between group members will be well established as well as the interaction between groups in the classroom (Adawiyah et al., 2020; Wahyuningtyas \& Shinta, 2017). Students with high critical thinking skills tend to be able to review the opinions given based on the knowledge they already have (Nugraha et al., 2017).

Contributions and implications based on the results above, the problems in formulating problems can be overcome motivate to ask questions to develop the courage to speak either face to face or online via WhatsApp. How to overcome the anxiety and possible boredom of learning by students by shifting learning from the teacher-centered learning system to the student center. Teachers can provoke students with problem-based questions when learning using a blended learning system because it increases critical thinking skills and understanding in formulating and explaining a problem. Teachers can design patterns of interaction and communication by using methods that emphasize more on effective information seeking. The use of e-modules can improve critical thinking. Learning by formulating problems through a virtual learning environment. How to overcome obstacles analyze and solve problems with teaching teachers based on problems in everyday situations to solve problems they face by using various sources of information. can get used to giving High Order Thinking Skills (HOTS) questions during face-to-face and online learning via WhatsApp. Combining blended learning system learning with problem-based learning models and the use of learning media. Parents are required to maintain the rhythm of student learning as appropriate learning at school. given procedural stages accompanied by pictures or videos to understand the instructions for experimental activities. The way to overcome the obstacles in evaluating is that the teacher as a facilitator helps the group build understanding and connect concepts by providing information, directing exploration, strengthening understanding of difficult concepts, and introducing resources. In addition, the facilitator asks for a reflection on the group process and group results. ask 
students to read a book first to help them understand the concept. Limitations in this research are the sources which only amount to 19 people and the limited time. Suggestions for teachers to use innovative learning methods and strategies to train students' critical thinking skills in science learning using a blended learning system, the existing constraints can be used as suggestions for next research, then it can be paid more attention to future researchers to further refine the research for further researchers can be used as references and considerations.

\section{CONCLUSION}

The integration of critical thinking skills which consists of formulating problems, analyzing and solving problems, and evaluating science learning has not been well integrated into elementary schools during the covid-19 pandemic. Teachers need to arrange creative learning in implementing blended learning system learning strategies so that critical thinking is a successful skill in learning science students can be achieved well. Creative learning strategies with a blended learning system need to be structured so that the success of critical thinking skills in learning science for students can be achieved properly as consideration for developing critical thinking skills in science learning with a blended learning system during the Covid-19 pandemic in elementary schools in the new normal era.

\section{REFERENCES}

Adawiyah, H., Gading, I. K., \& Bayu, G. W. (2020). Model Pembelajaran Cooperatif Integrated Reading Composition (CIRC) Meningkatkan Kemampuan Membaca Pemahaman Siswa. Jurnal Pedagogi dan Pembelajaran, 3(2), 233. https://doi.org/10.23887/jp2.v3i2.26465.

Alghafri, A. S. R., \& Ismail, H. N. Bin. (2014). The Effects of Integrating Creative and Critical Thinking on Schools Students' Thinking. International Journal of Social Science and Humanity, 4(6), 518-525. https://doi.org/10.7763/ijssh.2014.v4.410.

Alrahlah, A. (2016). How Effective the Problem-Based Learning (PBL) in Dental Education. A Critical Review. Saudi Dental Journal, 28(4), 155-161. https: //doi.org/10.1016/j.sdentj.2016.08.003.

Anazifa, R. D., \& Djukri. (2017). Project-Based Learning and Problem-Based Learning: Are They Effective to Improve Student's Thinking Skills? Jurnal Pendidikan IPA Indonesia, 6(2), 346-355. https: //doi.org/10.15294/jpii.v6i2.11100.

Andiarna, F., \& Kusumawati, E. (2020). Pengaruh Pembelajaran Daring terhadap Stres Akademik Mahasiswa Selama Pandemi Covid-19. Jurnal Psikologi, 16(2), 139. https: //doi.org/10.24014/jp.v16i2.10395.

Ariandari, W. P. (2015). Mengintegrasikan Higher Order Thinking dalam Pembelajaran Creative Problem Solving. Seminar Nasional Matematika dan Pendidikan Matematika Uny 2015, 489-496.

Bellaera, L., Weinstein-Jones, Y., Ilie, S., \& Baker, S. T. (2021). Critical Thinking in Practice: The Priorities and Practices of Instructors Teaching in Higher Education. Thinking Skills and Creativity, 41(May), 100856. https://doi.org/10.1016/j.tsc.2021.100856.

Bi, X., \& Shi, X. (2019). On the Effects of Computer-Assisted Teaching on Learning Results Based on Blended Learning Method. International Journal of Emerging Technologies in Learning, 14(1), 5870. https://doi.org/10.3991/ijet.v14i01.9458.

Boa, E. A., Wattanatorn, A., \& Tagong, K. (2018). The Development and Validation of the Blended Socratic Method of Teaching (BSMT): An Instructional Model to Enhance Critical Thinking Skills of Undergraduate Business Students. Kasetsart Journal of Social Sciences, 39(1), 81-89. https: //doi.org/10.1016/j.kjss.2018.01.001.

Budiarti, S., Nuswowati, M., \& Cahyono, E. (2016). Guided Inquiry Berbantuan E-Modul untuk Meningkatkan Keterampilan Berpikir Kritis. Journal of Innovative Science Education, 1(1), 1-9.

Çetin, A. (2016). An Analysis of Metaphors Used by High School Students to Describe Physics, Physics Lesson and Physics Teacher. European Journal of Physics Education, 7(2), 1-20. https://doi.org/10.20308/ejpe.35860.

Chang, T., Hsu, M., \& Kwon, J. (n.d.). Science Direct Effect of Online Learning for Dental Education in Asia during the Pandemic. Journal of Dental Sciences, $x x x x$. https://doi.org/10.1016/j.jds.2021.06.006.

Cortázar, C., Nussbaum, M., Harcha, J., Alvares, D., López, F., Goñi, J., \& Cabezas, V. (2021). Promoting Critical Thinking in an Online, Project-Based Course. Computers in Human Behavior, 119(February). https://doi.org/10.1016/j.chb.2021.106705.

Ćosić K, Popović S, Šarlija M, \& Kesedžić I. (2020). Impact of Human Disasters and Covid-19 Pandemic on Mental Health: Potential of digital psychiatry. Psychiatria Danubina [revista en Internet] 2020 [acceso 09 de noviembre de 2020]; 32(1): 25-31. Psychiatria Danubina, 32(1), 25-31.

Covid-, P., Hikmah, A. N., \& Chudzaifah, I. (2020). Blanded Learning : Solusi Model Pembelajaran Pasca. 6(2), 
83-94.

DeWaelsche, S. A. (2015). Critical Thinking, Questioning and Student Engagement in Korean University English Courses. Linguistics and Education, 32, 131-147. https://doi.org/10.1016/j.linged.2015.10.003.

Dewi, L. (2017). Rancangan Program Pembelajaran Daring di Perguruan Tinggi: Studi Kasus pada Mata Kuliah Kurikulum Pembelajaran di Universitas Pendidikan Indonesia. Edutech, 16(2), 205. https://doi.org/10.17509/e.v16i2.7616.

Diputra, S. (2018). Analisis Kemampuan Guru Melaksanakan Pembelajaran Tematik Terintegrasi Pendidikan Karakter. International Journal of Elementary Education, 2(2), 138. https: //doi.org/10.23887/ijee.v2i2.14416.

Essel, H. B., Nimo Nunoo, F. K., \& Ahiaklo-Kuz, N. A. Y. (2017). Development of an Integrated Art and Visual Programming Framework for Ghanaian Basic Schools Based on a 21st Century Skill Deficiency Diagnostic on Two Basic School Subjects. Journal of Education and Human Development, 6(4), 8998. https://doi.org/10.15640/jehd.v6n4a10.

Fitriyani, Y., Fauzi, I., \& Sari, M. Z. (2020). Motivasi Belajar Mahasiswa pada Pembelajaran Daring Selama Pandemi Covid-19. Profesi Pendidikan Dasar, 7(1), 121-132. https://doi.org/10.23917/ppd.v7i1.10973.

Gede Astawan, I., Tirtayani, L. A., Surya Mahayanti, N. W., Krishna Adnyani, K. E., Arthana, K. R., \& Dike, D. (2020). Trikaya Parisudha Learning Model and Its Effect on Critical Thinking Skill. European Journal of Molecular and Clinical Medicine, 7(6), 579-592.

Harris, D. N., \& Larsen, M. F. (2018). The Effects of the New Orleans Post-Katrina Market-Based School Reforms on Student Achievement, High School Graduation, and College Outcomes. Education Research Alliance, 1(1), 1-71.

Hart, C., Da Costa, C., D’Souza, D., Kimpton, A., \& Ljbusic, J. (2021). Exploring Higher Education Students' Critical Thinking Skills through Content Analysis. Thinking Skills and Creativity, 41(May), 100877. https://doi.org/10.1016/j.tsc.2021.100877.

Hasanah, H., Makassar, U. N., Street, A. P. P., Makassar, U. N., Street, A. P. P., Planning, H. E., \& Board, C. (2020). Cypriot Journal of Educational. 15(5), 1295-1306.

He, W., \& Zhao, L. (2020). Exploring Undergraduates' Learning Engagement Via BYOD in the Blended Learning Classroom (EULEBYODBLC). International Journal of Information and Education Technology, 10(2), 159-164. https://doi.org/10.18178/ijiet.2020.10.2.1356.

Herliandry, L. D., Nurhasanah, N., Suban, M. E., \& Kuswanto, H. (2020). Pembelajaran pada Masa Pandemi Covid-19. JTP - Jurnal Teknologi Pendidikan, 22(1), 65-70. https://doi.org/10.21009/jtp.v22i1.15286.

Huang, M. Y., Tu, H. Y., Wang, W. Y., Chen, J. F., Yu, Y. T., \& Chou, C. C. (2017). Effects of Cooperative Learning and Concept Mapping Intervention on Critical Thinking and Basketball Skills in Elementary School. Thinking Skills and Creativity, 23(101), 207-216. https: //doi.org/10.1016/j.tsc.2017.01.002.

Indraningtias, D. A., \& Wijaya, A. (2017). Pengembangan Perangkat Pembelajaran Berbasis Pendekatan Matematika Realistik Materi Bangun Ruang Sisi Datar Beorientasi pada Kemampuan Berpikir Kritis Siwa Kelas VIII SMP. Jurnal Pendidikan Matematika, 6(5), 24-36.

Indraswati, D., Marhayani, D. A., Sutisna, D., Widodo, A., \& Maulyda, M. A. (2020). Critical Thinking dan Problem Solving dalam Pembelajaran IPS untuk Menjawab Tantangan Abad 21. Sosial Horizon: Jurnal Pendidikan Sosial, 7(1), 12. https://doi.org/10.31571/sosial.v7i1.1540.

Indriyanti, N. Y., \& Yamtinah, S. (2020). An Inquiry into Students' Metacognition and Learning Achievement in a Blended Learning Design. International Journal of Emerging Technologies in Learning, 15(21), 77-88. https://doi.org/10.3991/ijet.v15i21.12907.

Irawan, Y., Susanti, N., \& Triyanto, W. A. (2015). Analisa dan Perancangan Sistem Pembelajaran Online (ELearning) pada SMK Mambaul Falah Kudus. Simetris: Jurnal Teknik Mesin, Elektro dan Ilmu Komputer, 6(2), 345. https://doi.org/10.24176/simet.v6i2.471.

Kacetl, J., \& Semradova, I. (2020). Reflection on Blended Learning and E-Learning - Case Study. Procedia Computer Science, 176, 1322-1327. https://doi.org/10.1016/j.procs.2020.09.141.

Kaeppel, K. (2021). The Influence of Collaborative Argument Mapping on College Students' Critical Thinking about Contentious Arguments. Thinking Skills and Creativity, 40(February), 100809. https://doi.org/10.1016/j.tsc.2021.100809.

Kar, S. K., Yasir Arafat, S. M., Kabir, R., Sharma, P., \& Saxena, S. K. (2020). Coping with Mental Health Challenges during Covid-19. 2019, 199-213. https://doi.org/10.1007/978-981-15-4814-7_16.

Kuhfeld, M., Soland, J., Tarasawa, B., Johnson, A., Ruzek, E., \& Liu, J. (2020). Projecting the Potential Impact of COVID-19 School Closures on Academic Achievement. Educational Researcher, 49(8), 549-565. 
https://doi.org/10.3102/0013189X20965918.

Laksana, D. N. L., Dasna, I. W., \& Degeng, I. N. S. (2019). The Effects of Inquiry-Based Learning and Learning Styles on Primary School Students' Conceptual Understanding in Multimedia Learning Environment. Journal of Baltic Science Education, 18(1), 51-62. https://doi.org/10.33225/jbse/19.18.51.

Lapitan, L. D., Tiangco, C. E., Sumalinog, D. A. G., Sabarillo, N. S., \& Diaz, J. M. (2021). An Effective Blended Online Teaching and Learning Strategy during the Covid-19 Pandemic. Education for Chemical Engineers, 35(May 2020), 116-131. https://doi.org/10.1016/j.ece.2021.01.012.

Lazem, S. (2019). On Designing Blended Learning Environments for Resource-Challenged Communities. International Journal of Emerging Technologies in Learning, 14(12), 183-192. https://doi.org/10.3991/ijet.v14i12.10320.

Lee, J. (2020). Mental Health Effects of School Closures during Covid-19. The Lancet Child and Adolescent Health, 4(6), 421. https://doi.org/10.1016/S2352-4642(20)30109-7.

Lim, C. L., Jalil, H. A., Marof, A. M., \& Saad, W. Z. (2020). Peer Learning, Self-Regulated Learning and Academic Achievement in Blended Learning Courses: A Structural Equation Modeling Approach. International Journal of Emerging Technologies in Learning, 15(3), 110-125. https://doi.org/10.3991/ijet.v15i03.12031.

Luo, Y., Geng, C., Pei, X., Chen, X., \& Zou, Z. (2021). The Evaluation of the Distance Learning Combining Webinars and Virtual Simulations for Senior Nursing Students during the COVID-19 Period. Clinical Simulation in Nursing, 57, 31-40. https://doi.org/10.1016/j.ecns.2021.04.022.

Marnita, Taufiq, M., Iskandar, \& Rahmi. (2020). The Effect of Blended Learning Problem-Based Instruction Model on Students' Critical Thinking Ability in Thermodynamic course. Jurnal Pendidikan IPA Indonesia, 9(3), 430-438. https://doi.org/10.15294/jpii.v9i3.23144.

McKenzie, S., Hains-Wesson, R., Bangay, S., \& Bowtell, G. (2020). A team-Teaching Approach for Blended Learning: An Experiment. Studies in Higher Education, o(0), 1-15. https: //doi.org/10.1080/03075079.2020.1817887.

Nugraha, A. J., Suyitno, H., \& Susilaningsih, E. (2017). Analisis Kemampuan Berpikir Kritis Ditinjau dari Keterampilan Proses Sains dan Motivasi Belajar melalui Model PBL. Journal of Primary Education, 6(1), 35-43. https://doi.org/https://doi.org/10.15294/jpe.v6i1.14511.

Phungsuk, R., Viriyavejakul, C., \& Ratanaolarn, T. (2017). Development of a Problem-Based Learning Model Via a Virtual Learning Environment. Kasetsart Journal of Social Sciences, 38(3), 297-306. https://doi.org/10.1016/j.kjss.2017.01.001.

Polizzi, C., Lynn, S. J., \& Perry, A. (2020). Stress and Coping in the Time of Covid-19: Pathways to Resilience and Recovery Craig Polizzi, Steven Jay Lynn, Andrew Perry. Clinical Neuropsychiatry, 59-62.

Purmadi, A., \& Hadi, M. S. (2018). Pengembangan Kelas Daring dengan Penerapan Hybrid Learning Menggunakan Chamilo pada Matakuliah Pendidikan Kewarganegaraan. Edcomtech Jurnal Kajian Teknologi ..., 135-140.

Pursitasari, I. D., Suhardi, E., Putra, A. P., \& Rachman, I. (2020). Enhancement of Student's Critical Thinking Skill through Science Context-Based Inquiry Learning. Jurnal Pendidikan IPA Indonesia, 9(1), 97105. https://doi.org/10.15294/jpii.v9i1.21884.

Rahmat, M. R., Arip, A. G., \& Nur, S. H. (2020). Implementation of Problem-Based Learning Model Assisted by E-Modules on Students' Critical Thinking Ability. JPI (Jurnal Pendidikan Indonesia), 9(3), 339. https: //doi.org/10.23887/jpi-undiksha.v9i3.22410.

Reflianto, \& Syamsuar. (2018). Pendidikan dan Tantangan Pembelajaran Berbasis Teknologi Informasi di Era Revolusi Industri 4.0. Jurnal Ilmiah Teknologi Pendidikan, 6(2), 1-13.

Riastini, P. N., \& Mustika, I. K. A. (2017). Pengaruh Model Polya terhadap Kemampuan Pemecahan Masalah Matematika Siswa Kelas V SD. International Journal of Elementary Education, 1(3), 189. https://doi.org/10.23887/ijee.v1i3.11887.

Ripoll, V., Godino-Ojer, M., \& Calzada, J. (2021). Teaching Chemical Engineering to Biotechnology Students in the Time of Covid-19: Assessment of the Adaptation to Digitalization. Education for Chemical Engineers, 34, 21-32. https://doi.org/10.1016/j.ece.2020.11.001.

Saptuti Susiani, T., Salimi, M., \& Hidayah, R. (2018). Research Based Learning (RBL): How to Improve Critical Thinking Skills? SHS Web of Conferences, 42, 00042. https://doi.org/10.1051/shsconf/20184200042.

Seage, S. J., \& Türegün, M. (2020). The Effects of Blended Learning on STEM Achievement of Elementary School Students. International Journal of Research in Education and Science, 6(1), 133-140. https: //doi.org/10.46328/ijres.v6i1.728.

Seibert, S. A. (2021). Problem-Based Learning: A Strategy to Foster Generation Z's Critical Thinking And Perseverance. Teaching and Learning in Nursing, 16(1), 85-88. 
https://doi.org/10.1016/j.teln.2020.09.002.

Shaheen, N. (2016). International Students' Critical Thinking-Related Problem Areas: UK University Teachers' Perspectives. Journal of Research in International Education, 15(1), 18-31. https://doi.org/10.1177/1475240916635895.

Shivam, R., \& Singh, S. (2015). Implementation of Blended Learning in Classroom: A Review Paper. International Journal of Scientific and Research Publications, 5(11), 369.

Sukardi, S., \& Rozi, F. (2019). Pengaruh Model Pembelajaran Online Dilengkapi dengan Tutorial terhadap Hasil Belajar. JIPI (Jurnal Ilmiah Penelitian dan Pembelajaran Informatika), 4(2), 97. https://doi.org/10.29100/jipi.v4i2.1066.

Susanti, B. H. (2019). Penggunaan Media Online dalam Proyek Pembuatan Bahan Ajar Berbasis Web pada Mata Kuliah Zoologi Vertebrata. Edusains, 11(1), 21-28. https://doi.org/10.15408/es.v11i1.7728.

Sutisna, D., Widodo, A., Nursaptini, N., Umar, U., Sobri, M., \& Indraswati, D. (2020). An Analysis of the Use of Smartphone in Students' Interaction at Senior High School. 465(Access 2019), 221-224. https://doi.org/10.2991/assehr.k.200827.055.

Tayag, J. R. (2020). Pedagogical Support for Blended Learning Classrooms: Interfacing Teacher and Student Perspectives. Universal Journal of Educational Research, 8(6), 2536-2541. https://doi.org/10.13189/ujer.2020.080637.

Turgut, U., Colak, A., \& Salar, R. (2016). The Effect of 7E Model on Conceptual Success of Students in The Unit of Electromagnetism. European Journal of Physics Education, 7(3), 1-37. https://doi.org/10.20308/ejpe.64317.

Wahyuni, S., Gusti Made Sanjaya, I., Erman, \& Jatmiko, B. (2019). Edmodo-Based Blended Learning Model as an Alternative of Science Learning to Motivate and Improve Junior High School Students' Scientific Critical Thinking Skills. International Journal of Emerging Technologies in Learning, 14(7), 98-110. https://doi.org/10.3991/ijet.v14i07.9980.

Wahyuningtyas, D. T., \& Shinta, R. N. (2017). Penggunaan Modul Pembelajaran Penjumlahan dan Pengurangan Bilangan Bulat dengan Pendekatan CTL (Contextual Teaching And Learning) untuk Meningkatkan Pemahaman Konsep Siswa Kelas IV Sekolah Dasar. Jurnal Pendidikan (Teori Dan Praktik), 2(1), 12. https://doi.org/10.26740/jp.v2n1.p12-20.

Wannapiroon, P. (2014). Development of Research-based Blended Learning Model to Enhance Graduate Students' Research Competency and Critical Thinking Skills. Procedia - Social and Behavioral Sciences, 136, 486-490. https://doi.org/10.1016/j.sbspro.2014.05.361.

Widiara, I. K. (2018). Blended Learning sebagai Alternatif Pembelajaran di Era Digital. Purwadita, 2(2), $50-56$.

Yalçin, S. A., Turgut, Ü., \& Büyükkasap, E. (2009). The Effect of Project Based Learning on Science Undergraduates' Learning of Electricity, Attitude towards Physics and Scientific Process Skills. International Online Journal of Educational Sciences, 1(1), 81-105.

Yu, T. X., \& Mohammad, W. R. W. M. (2019). Integration of 21st Century Learning Skills (4C Elements) in Interventions to Improve English Writing Skill Among 3K Class Students. International Journal of Contemporary Education, 2(2), 100. https://doi.org/10.11114/ijce.v2i2.4498.

Yu, Z., Hu, R., Ling, S., Zhuang, J., Chen, Y., Chen, M., \& Lin, Y. (2021). Effects of Blended Versus Offline CaseCentred Learning on the Academic Performance and Critical Thinking Ability of Undergraduate Nursing Students: A Cluster Randomised Controlled Trial. Nurse Education in Practice, 53(May), 103080. https://doi.org/10.1016/j.nepr.2021.103080.

Zou'bi, R. Al. (2021). The Impact of Media and Information Literacy on Acquiring the Critical Thinking Skill by the Educational Faculty's Students. Thinking Skills and Creativity, 39(November 2020), 100782. https://doi.org/10.1016/j.tsc.2020.100782. 